\title{
COMPARISON OF MATHEMATICAL MODELS FOR THE USE OF ENROFLOXACIN IN DOGS
}

\author{
Miroslav Vasilev, Galya Shivacheva \\ Faculty of Technics and Technologies of Yambol, \\ Trakia University of Stara Zagora, Bulgaria \\ Graf Ignatiev 38, 8600 Yambol, Bulgaria \\ e-mail: miroslav.vasilev@trakia-uni.bg
}

\begin{abstract}
This article analyzes the process of changing the concentration of enrofloxacin in blood plasma in dogs after a single intravenous injection of the substance. Three mathematical models are proposed - algebraic and two models, based on a differential equation of first and second order. Identification of their parameters has been performed. Based on Akaike information criterion corrected as the best model was chosen the represented by a second-order differential equation. Three equations are identified and the exact numerical values of their parameters are obtained. For the evaluation and comparison of the three models, Akaike information criterion was used. The best results showed the second-order differential model. It will be used in future developments.
\end{abstract}

Keywords: mathematical model, pharmacokinetics, enrofloxacin, Akaike information criterion, Korelia.

That which is static and repetitive is boring. That which is dynamic and random is confusing. In between lies art. John A. Locke (1632-1704), British philosopher and medical researcher

\section{INTRODUCTION}

Enrofloxacin is an antibacterial drug from the group of fluoroquinolones for use in veterinary medicine [2,4]. In [1], the change in its blood plasma concentration in dogs was studied in three ways of drug treatment - intravenous and subcutaneous injection and internal administration. Algebraic equations of these changes were compiled and their dynamic parameters compared. When describing dynamic processes, it is natural to use models based on differential equations. The established monotonic concentration change process is appropriate to be described with a first or second order differential equation. Of the three candidates for a mathematical model, it must be indicated that one meets a pre-selected criterion.

The purpose of this article is to select a mathematical model and assessment criterion that best approximates the change in enfufloxacin concentration in blood plasma in dogs after a single intravenous injection of the substance.

\section{MATERIAL AND METHODS}

The methodology for conducting the experiment and reporting the results are outlined in [2]. The data is represented by their mean value and standard deviation. 


\section{ARTTIE $Y$}

Ipplied Reseitrones in Technics, Technologies and Bductition

Journal of the Faculty of Technics and Technologies, Trakia University https://sites.google.com/a/trakia-uni.bg/artte/

\subsection{Software used}

The data processing and analysis was carried out with specialized software from the KORELIA family. The User-Oriented Interface [12] and the Exploration Process Recognition module $[8,11]$ facilitate data entry and support the choice of a mathematical model. The identified equations [7] can be analyzed and compared by a number of parameters [9] and thus find the most appropriate for the particular set [10].

The minimization of the square error was used as the optimization criterion. A qualitative criterion for assessing the proximity of identified parameters to the experimental data of a particular model is the coefficient of determination $\mathrm{R}^{2}$.

Since three models are described with different equations, it is not permissible that their proximity to the data be assessed by the determinant factor. Appropriate for this case is Akaike information criterion, AIC $[3,6]$.

$$
A I C=N \cdot \ln \left(\frac{D(Q)^{2}}{N}\right)+2 \cdot(K+1)
$$

where: $\mathrm{N}$ - number of information points;

$D(Q)^{2}-$ sum of the squares of the verticals

deviations from each data point to the "optimal"

approaching curve

$\mathrm{K}$ - number of identification parameters

When the number of information points $\mathrm{N}$ is small compared to $\mathrm{K}\left(\frac{N}{K}<40\right)$, it is necessary to use the corrected version of the Akaike information criterion (AICc) [5, 6].

$$
A I C C=A I C+\frac{2 \cdot K \cdot(K+1)}{N-K}
$$

If $\mathrm{N} \rightarrow \infty$ the values of the two criteria are approaching.

In cases where the results of the AICc are very close, it is necessary to use additional criteria to assess the models. From AICc, the model's reliability can be calculated (Probability of the model - $\mathrm{P}_{\mathrm{I}, \mathrm{J}}$ ).

$$
\begin{gathered}
P_{I, J}=\frac{1}{1+e^{0.5 \Delta_{I, J}}} \\
\text { where: } \begin{array}{l}
\Delta_{I, J}=A I C c_{I}-A I C c_{J} \\
I, J-\text { numbers of the models compared. }
\end{array}
\end{gathered}
$$

When comparing, the Evidence Ratio $\left(E R_{l, J}\right)$ can also be used, representing the relationship of the reliability of two compared models:

$$
E R_{I, J}=\frac{P_{I, J}}{P_{J, I}}=e^{-0.5 \Delta_{I, J}}
$$

\subsection{Mathematical models}

Three mathematical models have been identified. 


\section{IRTTIE Ipplied Researl'ches in Technics, Technologies and Bducation Journal of the Faculty of Technics and Technologies, Trakia University https:///sites.google.com/a/trakia-uni.bg/artte/}

\subsubsection{Algebraic model (Model 1)}

In [1], the algebraic model used, which is a solution of the first order differential equation.

$$
\mid \begin{aligned}
& y(t)=\left(C_{0}-C_{\infty}\right) \cdot e^{-r \cdot t}+C_{\infty} \\
& C_{\infty}=\lim _{t \rightarrow \infty} y(t)=\frac{K \cdot U}{r}
\end{aligned}
$$

where: $\mid \mathrm{U}(\mathrm{t})$ - a dose of enrofloxacin;

$\mathrm{C}_{0}-$ initial value.

Identification parameters are:

$$
\begin{aligned}
& r \text { - the rate constant of the process; } \\
& K \text { - coefficient of sensitivity. }
\end{aligned}
$$

\subsubsection{Differential first-order model (Model 2)}

$$
\begin{gathered}
\qquad \begin{array}{l}
\frac{d y(t)}{d t}+r \cdot y(t)=K \cdot U(t) \\
\mathrm{y}(0)=\mathrm{C}_{0}-\text { initial condition }
\end{array} \\
\text { where: } \mid \mathrm{U}(\mathrm{t}) \text { - a dose of enrofloxacin }
\end{gathered}
$$

Identification parameters are:

$$
\begin{aligned}
& r-\text { the rate constant of the process; } \\
& K \text { - coefficient of sensitivity. }
\end{aligned}
$$

\subsubsection{Second-order Differential Model (Model 3)}

It is presented by the equation:

$$
\mid \begin{aligned}
& \frac{d^{2} y(t)}{d t^{2}}+2 . \zeta \cdot \omega \cdot \frac{d y(t)}{d t}+\omega^{2} y=K \cdot \omega^{2} \cdot U(t) \\
& y(0)=\mathrm{C}_{0} \quad \text { initial conditions } \\
& \frac{d y(0)}{d t}=0 \quad
\end{aligned}
$$

where: | $\mathrm{U}(\mathrm{t})$ - a dose of enrofloxacin.

Identification parameters are:

$\zeta$ - damping ratio;

$\omega$ - natural frequency;

$\mathrm{K}-$ coefficient of sensitivity.

IRTTIE Vol. 7, No. 2, 2019 ISSN 1314-8788 (print), ISSN 1314-8796 (online), doi: 10.15547/artte.2019.02.004 


\section{IRITIE}

Ipplied Researl'ches in Technics, Technologies and Bducation

Journal of the Faculty of Technics and Technologies, Trakia University https:///sites.google.com/a/trakia-uni.bg/artte/

\section{RESULTS AND DISCUSSION}

KORELIA-Ident software was used to calculate the identification parameters for each of the three models. The results are shown in Table 1.

Table 1. Values of the identified parameters of the three models

\begin{tabular}{|l|c|c|c|c|}
\hline & $\mathrm{r}$ & $\mathrm{k}$ & $\zeta$ & $\omega$ \\
\hline Model 1 & 0,2630 & 0,0042 & - & - \\
\hline Model 2 & $-0,2360$ & 0,0001 & - & - \\
\hline Model 3 & - & $-0,0880$ & 6,0000 & 3,4000 \\
\hline
\end{tabular}

Model equations are:

Model 1

$$
y(t)=1.516 \cdot e^{-0.263 t}+0.080
$$

Model 2

$$
\frac{d y(t)}{d t}+0.2365 . y(t)=0.0005
$$

Model 3

$$
\frac{d^{2} y(t)}{d t^{2}}+40.8 \frac{d y(t)}{d t}+11.56 y=-5.0865
$$

The graphs of the models are in Figure 1.

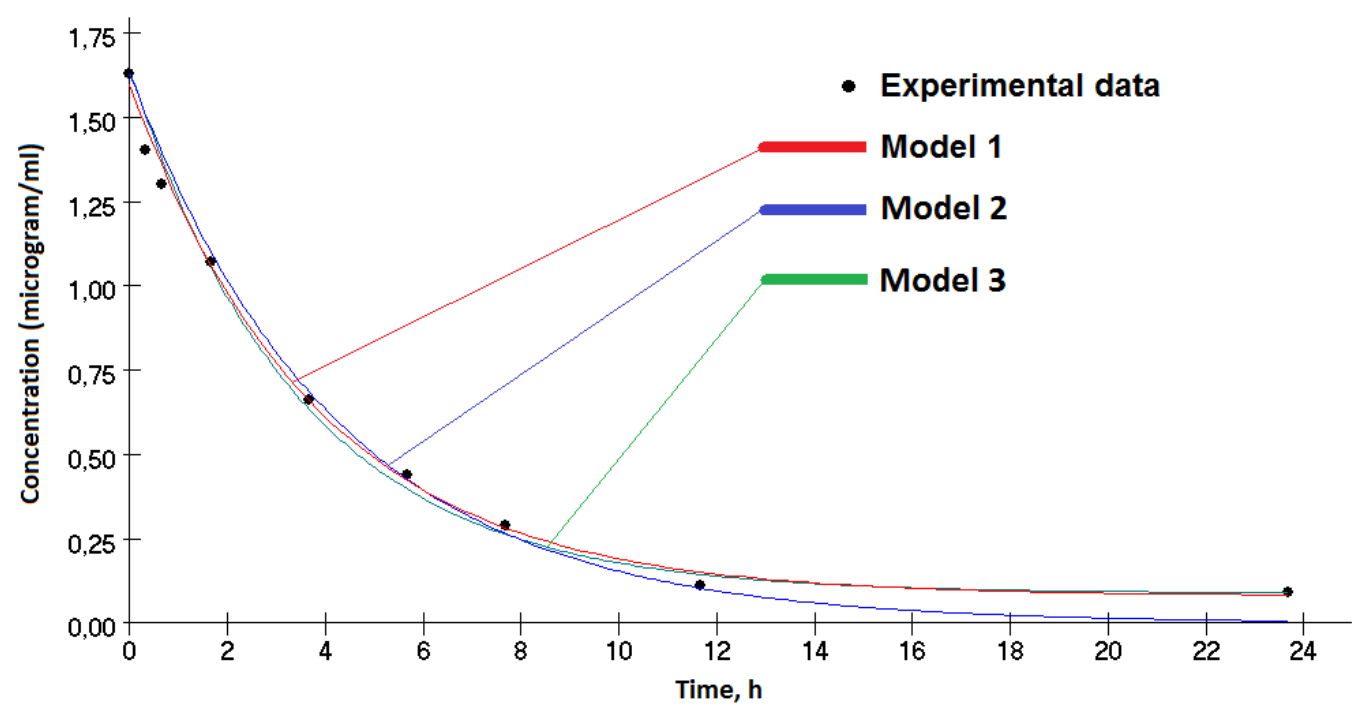

Figure 1. Changes in enrofloxacin concentration in the three models

Table 2 presents the parameters that are used to compare the three mathematical models. The values for $\mathrm{R}^{2}$, quadratic error, AIC and AICc were obtained using the identification software. The credibility of the model and the proof coefficient are calculated by formulas (3)

IRTTIE Vol. 7, No. 2, 2019 ISSN 1314-8788 (print), ISSN 1314-8796 (online), doi: 10.15547/artte.2019.02.004 


\section{ARTTIE $Y$}

Ipplied Reseitrones in Technics, Technologies and Bductition

Journal of the Faculty of Technics and Technologies, Trakia University https://sites.google.com/a/trakia-uni.bg/artte/

and (4). To choose a model, the corrected version of AIC is used, as the $\mathrm{N}$ and $\mathrm{K}$ research processes are relatively close.

Table 2. Comparative parameters of the identified models

\begin{tabular}{|c|c|c|c|c|c|c|c|}
\hline Model & $\mathrm{R}^{2}$ & $\begin{array}{c}\text { Quadratic } \\
\text { error }\end{array}$ & AIC & AICc & $\Delta$ AICc & $\mathrm{P}_{\mathrm{I}, \mathrm{J}}$ & $\mathrm{ER}_{\mathrm{I}, \mathrm{J}}$ \\
\hline Model 3 & 0,990 & 0,027 & -2421 & -2413 & & & \\
\hline Model 2 & 0,986 & 0,038 & -2330 & -2326 & 87,127 & $1,2037 \mathrm{E}-19$ & $830775 \mathrm{E}+18$ \\
\hline Model 1 & 0,996 & 0,011 & -52 & -43 & 2370 & 0 & $\infty$ \\
\hline
\end{tabular}

For the "optimal" model according to the AICc criterion, the one with the smallest value is selected. The implementation of this condition is the second-order differential model Model3. The values of $\mathrm{P}_{\mathrm{I}, \mathrm{J}}$ and $E \mathrm{R}_{\mathrm{l}, \mathrm{J}}$ show that the three models differ from one another.

\section{CONCLUSION}

Based on the experiment, three mathematical models - algebraic, first order differential, and second order differential - have been developed describing the change in the concentration of enrofloxacin in blood plasma in dogs after intravenous treatment. Three equations are identified and the exact numerical values of their parameters are obtained. For the evaluation and comparison of the three models, Akaike information criterion was used. The best results showed the second-order differential model. It will be used in future developments.

\section{ACKNOWLEDGEMENTS}

This study was supported by the Scientific Project: 2.FTT/ 31.03.2017 „Investigation of systems and processes by the phase plane method" of the Faculty of Technics and Technology, Yambol, Trakia University - Stara Zagora, Bulgaria.

The authors express their deep gratitude to Prof. Dimitrichka Dimitrova, University of Forestry, Sofia, Bulgaria for the provided data, without which this work would not have been possible.

\section{REFERENCES}

[1] Vasilev M., Dimitrova D., Shivacheva G. (2015). Dynamic parameters for assessment of the pharmacokinetics of enrofloxacin to dogs. ARTTE Applied Researches in Technics, Technologies and Education, Vol. 3, No. 3, 2015, ISSN1314-8796, pp. 234-241.

[2] Dimitrova D. (2013). Comparative study of the pharmacokinetics of enrofloxacin in dogs and cats, Pharmacokinetics of some antimicrobial chemotherapeutics in veterinary medicine, Litera print, Stara Zagora, 2013, pp. 93-101. (in Bulgarian).

[3] Anderson D., Burnham K. (1999). Understanding Information Criteria for Selection Among Capture-Recapture or Ring Recovery Models. Bird Study. Vol. 46, 1999, pp. 1421.

[4] Bratoev N., Milanova A., Dimitrova D., Moutafchieva R., Pavlova I., Lashev L. (2017). The pharmacokinetics of enrofloxacin in ducks with steatosis after force-feeding. Veterinarski Arhiv, 87 (2), 2017, ISSN 0372-5480, pp. 209-219.

[5] Hamparsum B. (2000). Akaike's Information Criterion and Recent Developments in Information Complexity. Journal of Mathematical Psychology, Vol. 44, 2000, pp. 62-91.

[6] Motulsky H., Christopoulos A. (2003). Fitting models to biological data using linear and nonlinear regression. A practical guide to curve fitting. GraphPad Software Inc., 2003, p. 351.

IRTTIE Vol. 7, No. 2, 2019 ISSN 1314-8788 (print), ISSN 1314-8796 (online), doi: 10.15547/artte.2019.02.004 


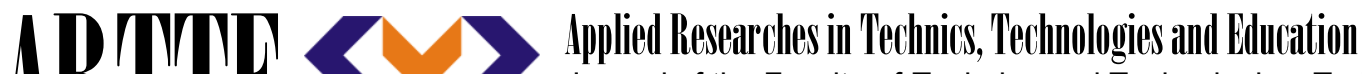 Journal of the Faculty of Technics and Technologies, Trakia University https://sites.google.com/a/trakia-uni.bg/artte/}

[7] Yankov K. (2006). System Identification of Biological Processes. Proc. 20-th Int. Conf. "Systems for Automation of Engineering and Research (SAER-2006). St. St. Constantine and Elena resort, Sept. 23-24, 2006, Varna, Bulgaria, 2006, pp. 144-149. ISBN 954-438-575-4.

[8] Yankov K. (2010). Decision Planning of System Identification. Proc. of the Int. Conference on Information Technologies (InfoTech-2010). St. St. Constantine and Elena resort, Sept.16-18, 2010, Varna, Bulgaria, ISSN 1314-1023, pp. 229-238.

[9] Yankov K. (2015). Assessment of Processes Using Identification Models. ARTTE Applied Researches in Technics, Technologies and Education, Vol. 3, No. 1, 2015, ISSN 1314-8796, pp. 52-60. doi: 10.15547/artte.2015.01.006.

[10] Yankov K. (2015). Selection of the Approximating Function for Isobologram Modeling. Proc. Int. Conference on Information Technologies (InfoTech-2015). St. St. Constantine and Elena resort, Varna, Bulgaria, Sept. 17-19, 2015, ISSN 1314-1023, pp. 174-183.

[11] Yankov K. (2009). Recognition and Function Association of Experimental Data. Proc. of the Int. Conference on Information Technologies (InfoTech-2009). St. St. Constantine and Elena resort, Sept.17-20, 2009, Varna, Bulgaria, pp. 131-140.

[12] Yankov K., Ilieva D. (2015). User Interface for Analysis of Experimental Data. Trakia Journal of Sciences, Vol. 13, Suppl. 1, ISSN 1313-3551, pp. 420-425. doi:10.15547/tjs.2015.s.01.072. 